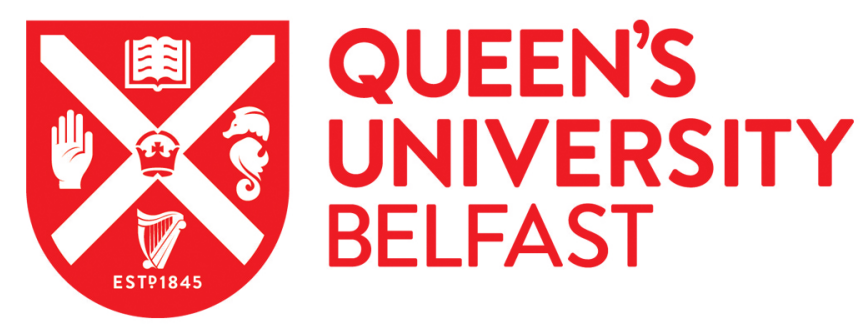

\title{
Radiation therapy-induced metastasis radiobiology and clinical implications
}

Blyth, B. J., Cole, A. J., MacManus, M. P., \& Martin, O. A. (2017). Radiation therapy-induced metastasis radiobiology and clinical implications. Clinical \& Experimental Metastasis, 1-14. https://doi.org/10.1007/s10585017-9867-5

Published in:

Clinical \& Experimental Metastasis

Document Version:

Peer reviewed version

Queen's University Belfast - Research Portal:

Link to publication record in Queen's University Belfast Research Portal

Publisher rights

(C) Springer Science+Business Media B.V., part of Springer Nature 2017. This work is made available online in accordance with the publisher's policies. Please refer to any applicable terms of use of the publisher.

\section{General rights}

Copyright for the publications made accessible via the Queen's University Belfast Research Portal is retained by the author(s) and / or other copyright owners and it is a condition of accessing these publications that users recognise and abide by the legal requirements associated with these rights.

Take down policy

The Research Portal is Queen's institutional repository that provides access to Queen's research output. Every effort has been made to ensure that content in the Research Portal does not infringe any person's rights, or applicable UK laws. If you discover content in the Research Portal that you believe breaches copyright or violates any law, please contact openaccess@qub.ac.uk. 


\title{
Radiation therapy-induced metastasis: radiobiology and clinical implications
}

\author{
Benjamin J Blyth ${ }^{1,2^{*}}$, Aidan J Cole ${ }^{1,3}$, Michael P MacManus ${ }^{1,4}$ and Olga A Martin ${ }^{1,2,4}$
}

${ }^{1}$ Division of Radiation Oncology and Cancer Imaging, Peter MacCallum Cancer Centre, 305 Grattan Street, Melbourne, 3000, Australia

${ }^{2}$ Cancer Research Division, Peter MacCallum Cancer Centre, 305 Grattan Street, Melbourne, 3000, Australia

${ }^{3}$ Centre for Cancer Research and Cell Biology, Queen's University Belfast, Lisburn Road, Belfast, BT9 7BL, UK

4 The Sir Peter MacCallum Department of Oncology, The University of Melbourne, Parkville, VIC, 3010, Australia

* Correspondence to BJB: E-mail: benjamin.blyth@petermac.org ; Phone: +61-3-85597115 ;

ORCID: orcid.org/0000-0003-4754-6249

\section{Keywords:}

Radiotherapy; Metastasis; EMT; Abscopal Effects; Circulating Tumour Cells

\section{Acknowledgements:}

We would like to acknowledge the assistance of Ms Diane Russo in preparation of the manuscript. This work was supported by a grant from the Australian National Health and Medical Research Council (NHMRC \#1104139).

\section{Article Type:}

Invited Review, Special Issue: Treatment-Induced Metastasis

\begin{abstract}
Abbreviations:
Circulating tumour cell (CTC); non-small cell lung cancer (NSCLC); 3D-conformal radiotherapy (3D-CRT); intensity-modulated radiotherapy (IMRT); volumetric modulated arc therapy (VMAT); flattening filter-free (FFF); microbeam radiotherapy (MRT); transforming growth factor- $\beta 1$ (TGF- $\beta$ ); matrix metallo-proteinase (MMP); epithelial-to-mesenchymal transition (EMT).
\end{abstract}

\section{Conflict of Interest Statement:}

The authors have no conflict of interest to declare.

\begin{abstract}
Radiation therapy is an effective means of achieving local control in a wide range of primary tumours, with the reduction in the size of the tumour(s) thought to mediate the observed reductions in metastatic spread in clinical trials. However, there is evidence to suggest that the complex changes induced by radiation in the tumour environment can also present metastatic risks that may counteract the long-term efficacy of the treatment. More than 25 years ago, several largely theoretical mechanisms by which radiation exposure might increase metastatic risk were postulated. These include the direct release of tumour cells into the circulation, systemic effects of tumour and normal tissue irradiation and radiation-induced changes in tumour cell phenotype. Here, we review the data that has since emerged to either support or refute these putative mechanisms focusing on how the unique radiobiology underlying modern radiotherapy modalities might alter these risks.
\end{abstract}




\section{MANUSCRIPT TEXT}

The idea that radiation therapy used to treat tumours might also contribute to tumour metastasis is not a new one, having been described in pre-clinical and clinical studies for at least 60 years [1], alongside effects documented for other cancer treatments and interventions, reviewed in [2]. In a comprehensive review of radiation-induced enhancement of metastasis in 1991, von Essen described four mechanisms that might be considered to influence radiation-induced metastasis [3], namely: radiation-induced release of tumour cells into the circulation; effects at distant normal tissue sites which might host metastases; radiation-induced changes in surviving tumour cells; and, local control-mediated prolonging of metastatic cell release. Although our understanding in these areas has grown considerably, these same four prospective modes of radiotherapy-mediated effects on tumour metastasis remain relevant in current discussions on the topic. While the evidence available more than 25 years ago to support the mechanism of radiation-induced circulating tumour cell (CTC) release was limited to in vitro proof-of-principle and experiments in animal models of transplanted tumours, our group recently reported that early in the course of radiotherapy, some patients with non-small cell lung cancer (NSCLC) showed release of CTCs or clusters containing multiple CTCs into the circulation [4]. Other clinical evidence supporting the effect of radiotherapy on distant metastasis has also begun to mount, reviewed in [5]. In the time since von Essen outlined the abovementioned four modes of radiation-induced metastasis, not only has there been much work into investigating these mechanisms, utilising advances in cellular and molecular biology, but the nature of radiation therapy itself has also changed dramatically. Here, we will discuss the progress that has been made in the investigation of these mechanisms, with particular focus on the changing radiotherapy landscape and the impact of modern and future radiotherapy modalities.

\section{The Changing Landscape of Radiation Therapy}

Radiation therapy remains the most effective non-surgical technique to achieve control of malignant tumours [6]. It can be utilised at each stage of the patient journey to: downstage primary tumours, reduce the risk of recurrence in the adjuvant setting, and in palliative settings to improve symptoms and quality of life. Whilst radiation therapy has been in use for over a century, the past two decades have seen an exponential increase in technological advances aimed at improving tolerability, accuracy and efficacy.

Technical advances have been made in both treatment planning and delivery. Increased sophistication in imaging and treatment planning system algorithms allow for ever-increasing ease and precision in localisation and 
demarcation of the target volume, providing the input for the integrated radiation delivery systems. However, developments in precision ultimately reach a plateau as the dose and physical uncertainties fall below the biological uncertainty of where the optimal lines should be drawn, such that the largest source of error becomes doubt in how to optimally define the target volume to achieve maximal biological response. The improvements in treatment planning and associated physical-spatial-temporal models allowed the evaluation of all possible permutations for how to deliver the desired dose to the target volume, leading to novel technological and strategic approaches to the physical delivery of photon irradiation [7,8], such as 3D-conformal radiotherapy (3D-CRT), intensity-modulated radiotherapy (IMRT) and volumetric modulated arc therapy (VMAT). However, where the desired dose-distribution to the target entered into the models is the same, these varied approaches all ultimately achieve similar irradiation of the target volume, but with various compromises in the dose distribution in the surrounding normal tissues $[9,10]$. The relative advantages of these competing photon radiotherapy technologies thus depend on whether minimizing total dose, maximum dose or irradiated volume in normal tissues is preferable (a question of ongoing debate, [11]), and other factors such as cost, ease and flexibility. With increased ability to spare normal tissues, these novel photon radiotherapy modalities can also allow for increasing tumour doses and altering other treatment parameters [12,13], in line with results from clinical trials [14].

Novel radiotherapy modalities such as stereotactic radiotherapy, brachytherapy, and proton and carbon ions are also becoming increasingly prevalent, reviewed in [15]. Historically, radiotherapy has been delivered in a fractionated manner with five daily fractions per week each of $2 \mathrm{~Gy}$, with the convenience of such schedules overlapping with the justification of allowing time between fractions for normal tissue recovery. Coupled with the benefits to sparing of normal tissue, fractionation can also have benefits in terms of tumour control including: limiting repopulation, improvement in oxygenation and allowing for cell cycle changes whereby tumour cells can move into the more sensitive G2/M phase of the cell cycle, reviewed in [16]. Such fractionation has been used since Coutard proposed it in 1934 [17], with the linear quadratic cell-killing model and derived alpha/beta $(\alpha / \beta)$ ratios underpinning the radiobiological effects of fractionation on tumours and normal tissues [18]. Yet despite their sparing effects of normal tissues, increased fraction delivery time and duration of treatment course have been implicated in reduced treatment efficacy [19,20], allowing for repopulation and recovery of tumour cells via sublethal damage repair. Accelerated radiotherapy has been found to show improvements in local control in head and neck cancer [21] and increases in overall survival in lung cancer [22,23]. Conversely, the delivery of larger fraction doses in stereotactic treatments often requires intra-fraction imaging with cone-beam computed tomography $(\mathrm{CT})$ or other imaging techniques, which may prolong fraction delivery. By decreasing fraction 
delivery times [24], the use of VMAT and flattening filter-free (FFF) treatment aim to negate potentially detrimental biological consequences including intra-fraction motion and tumour recovery. Clinical trials of stereotactic radiotherapy utilise a variety of fractionation regimens based on tumour volume, site of disease and proximity to organs at risk [25-27]. Despite the higher radiation levels delivered to the tumour, there may only be limited increases in cell kill due to the higher $\alpha / \beta$ ratio of hypoxic clonogens [28], while losing the benefits of reoxygenation observed with conventional fractionation. Many studies have reviewed the applicability of the linearquadratic model to hypo-fractionation with no clear consensus on its validity $[18,29,30]$.

Beyond fractionation, there are other exposure parameters related to modality and delivery that may impact on the cells' individual responses to treatment, including radiation quality and dose-rate (Figure 1). Charged particle therapies, primarily proton and carbon ion beams, take advantage of the favourable physical properties of charged particles which deposit dose in a sharp and narrow peak close to the end of their range, reviewed in [31,32]. The lower entrance doses and minimal exit doses mean that the dose delivered to organs at risk is significantly lower than for external-beam radiotherapy techniques. The relative biological effectiveness of protons is marginally higher than reference X-rays (particularly at the end of the track, [33]) but markedly increases with the use of heavier ions, preferentially within the target volume. These differences in both dose localisation and relative biological effectiveness, as well as interactions with tumour hypoxia [32], mean that the radiobiology of chargedparticle therapies could have unforeseen implications for radiation-enhanced metastasis [34].

Brachytherapy uses implanted radioactive 'seeds' to deliver higher biologically-effective doses close to the tumour tapering off to low doses at the borders with surrounding tissues, and has been shown to be effective in curing low-risk prostate cancers and is a key component of the management of gynaecological malignancies. One of the attractive features of brachytherapy is the ability to deliver a high dose-rate [35], a feature also shared with FFF treatments (with average dose rates of up to 0.5 Gy per second, [36]) and proton pencil beam scanning which can reach up to Gy per millisecond dose-rates [37]. Recently, small animal irradiation platforms delivering up to 50 Gy per second photon irradiation (so-called FLASH irradiation protocols) have shown optimal tumour control and a reduction in normal tissue toxicity [38], furthering interest in the development of clinical linear accelerators able to achieve such dose-rates. A new modality known as microbeam radiotherapy (MRT), in which the high dose-rate X-ray beam is split into an array of planar parallel microbeams, has shown promise in sparing normal tissues while still achieving tumour cell kill [39,40]; although, it is currently only achievable in synchrotron facilities. Although clinical implementation of MRT is some time away [41], it is considered to be a technically 
feasible alternative to conventional broad-beam radiotherapy.

Whilst these various novel treatments offer potential improvements in side-effect profiles and improved efficacy for tumour control, the radiobiological implications of the altered radiation exposure parameters for the tumour and its microenvironment remain under investigation. Although a key element of the consent process for any cancer intervention, including radiotherapy, is informing patients of the risks and side effects of the treatment, it is an implicit assumption that the proposed treatment will not increase the chances of metastatic disease, often the ultimate cause of cancer mortality. The unfavourable propositions that an intervention to achieve cure can simultaneously disseminate malignant cells into the circulation, and/or increase the metastatic potential of any remaining tumour cells, are however plausible ones.

\section{Release of Tumours Cells into the Circulation}

Many patients succumb to distant metastases despite optimal loco-regional control of primary lesions (Figure 2), primarily attributed to so-called occult micro-metastases which were already present at the time of diagnosis [4244]), with subsequent growth at these distant sites appearing once a supportive vascular network is established. An alternative, and non-exclusive mechanism is that malignant cells may also be released into the circulation by iatrogenic (caused by a medical intervention) disruption of the tumour. Ebos drew a parallel to Hercules' battle with the Lernaean Hydra in Greek Mythology i.e. for each head cut off, two more sprung up to replace it [2]. It is possible that pre-existing or treatment-induced metastasis may be responsible in different patients, or even occur in parallel in the same patient. It is also plausible that radiation treatment of pre-existing metastatic lesions may spawn the spread of further metastases.

All treatments for cancer including surgery, chemotherapy and radiotherapy have been implicated in changes to the cancer cell and its environment which can release tumour cells into the surrounding vasculature and enable tumour cells to develop phenotypes which can lead to metastatic spread, reviewed in [2]. A number of pre-clinical studies have clearly indicated the potential for radiation to enhance metastatic disease [45], with a variety of mechanisms now clearly established (Figure 3). Despite this, the clinical data from human studies has failed to uncover a clear pro-metastatic effect, most likely due to the diversity of human tumour responses. This was illustrated in a mouse xenograft model, where rhabdomyosarcoma lines derived from two different patients showed opposing effects of local fractionated irradiation to the subcutaneous implants on metastatic spread [46]. 
Reviews of a range of studies into the prognostic significance of CTC levels have concluded that the number of CTCs is an independent predictor of distant metastasis [47], but whether the most relevant time-point for analysis is before, during or after treatment is still unclear. A study comparing CTC release in uveal melanoma patients undergoing different treatments showed that 3 out of 49 patients undergoing stereotactic radiotherapy were positive for CTCs post-treatment, compared to 0 out of 15 patients treated with brachytherapy [48], but more data in this area are needed before direct comparisons can be made, particularly given the immense challenge of detecting rare CTCs [49]. A study in NSCLC patients treated with proton therapy or intensity-modulated radiation therapy demonstrated a trend towards decreasing CTC counts during and following either radiotherapy modality [50]. In one case, high CTC levels during treatment increased further following radiotherapy, with the patient soon diagnosed with distant failure. In a mouse model, irradiation of sub-cutaneous implanted melanomas with high dose-rate gamma-rays $(2.5 \mathrm{~Gy} / \mathrm{min})$ was more effective at both local control and reduction in metastasis to the lungs compared with the same dose delivered at low dose-rate ( $40 \mathrm{mGy} / \mathrm{min})$, although both dose-rates reduced metastasis compared to unirradiated animals [51]. However, whether such differences are relevant to the much higher dose-rates now coming into use in clinical radiotherapy is unclear, as is whether the reduced metastatic risk is a secondary measure of improved local control or includes an effect of treatment on metastasis directly. The development of mouse models for testing relevant radiotherapy treatment plans [45], including stereotactic radiotherapy in oligo-metastatic disease [52] will assist in answering such questions. The risk associated with potential CTC release induced by ablative hypo-fractionated doses delivered to metastatic sites is unclear, especially where such treatments are non-curative [53]. There are currently no data available on the ability of modalities such as carbon ion therapy, FLASH radiotherapy or MRT to induce the release of tumour cells into the circulation. Despite the abundance of clinical trials into various radiotherapy modalities, regimens and combinedtherapies, there is still a significant lack of knowledge as to how the parameters of dose, dose-rate, fractionation and radiation quality influence any radiotherapy-enhanced CTC release. Since local control and side-effect profiles are the primary metrics for comparing novel radiotherapy treatments against current standard-of-care, and distant-metastasis (either spontaneous or treatment-induced) is already monitored, it is not expected that the potential for CTC release alone would influence the selection of any one modality in the absence of inferior metastatic outcomes. Yet, if radiotherapy-induced CTCs were found to be significantly higher for an otherwise attractive modality, it represents a potential target for further improving the long-term success of such treatments.

\section{Effects in Irradiated Non-Tumour Cells and at Distant Non-Irradiated Sites}


Another of the mechanisms for radiation-enhanced metastasis hypothesised by von Essen, was that radiation might influence metastatic risk indirectly through effects on non-tumour cells. Evidence for radiation-induced bystander effects suggests that cells in an irradiated volume can induce biological changes in neighbouring unirradiated cells by inter-cellular communication, reviewed in [54,55], an effect that appears to be highly dependent on radiation quality with implications for charged particle therapies [56]. Lethally-irradiated tumour cells have long been shown to be able to promote malignant growth when mixed and co-injected with non-irradiated viable cells in animal models [57,58], an effect not observed with heat-killed tumour cells. It has also been demonstrated that the normal tissue/stroma surrounding an irradiated tumour may become both more hostile to a re-growing tumour and more permissive to tumour cell escape, known as the tumour bed effect, reviewed in [59-61]. This is particularly relevant when radiotherapy is used in an adjuvant setting, such as after breast conservation surgery. In this case, irradiation of the presumptive normal breast surrounding the tumour excision site is effective at preventing local recurrence [62], presumably mediated by eradication of invasive tumour cells that remain outside of the surgical margins. However, radiation-induced pro-metastatic effects on the normal breast tissue could still be an issue, potentially reducing the efficacy of such treatments particularly given the high rates of ipsilateral recurrence [63].

The systemic extrapolation of bystander effects, known as the abscopal effect, involves physiological changes induced by irradiation of a defined volume [64], and is usually associated with anecdotal descriptions of responses in tumours distant from the primary irradiated site, reviewed in $[65,66]$. Yet, mechanisms of a pro-metastatic nature have also been described. Radiation treatment to a subcutaneously-implanted tumour in mice led to the activation of dormant micro-metastases [67] via the removal of the suppressive effects of angiostatin which had been secreted by the tumour, consistent with what had been observed in anecdotal cases following surgical removal of a primary tumour. It has since been shown that growing tumours can induce a wide range of systemic effects via plasma cytokines resulting in inflammation and DNA damage at distant sites [68], responses which might be further altered by radiotherapy-induced tumour cell kill. Even irradiation of normal tissue increases the plasma concentration of circulating transforming growth factor- $\beta 1$ (TGF- $\beta$ ), corresponding to increased metastatic spread in a transgenic breast cancer mouse model [69], while in another model plasma interleukin-1 $\beta$ (IL-1 $\beta$ ) levels rose during radiotherapy treatment [45], a cytokine which when delivered at high dose was extremely pro-metastatic. Similar conflicts as those observed between pro- and anti-metastatic effects of local irradiation have also been described in chemotherapy models of treatment-induced metastasis [70,71]. 
Abscopal effects mediated by the immune system have been explored for potential clinical exploitation [72,73]. Such effects are implicated in results showing that carbon ion irradiation of a primary implanted tumour in mice prevents the growth of a second tumour after inoculation challenge [74], with the suggestion that heavy ions might have an inherent advantage for such mechanisms [75]. Evidence for immunogenic activation of anti-tumour defences has also been observed for proton irradiation [76]. It is thought that tumour vascular damage due to the high doses used in stereotactic radiotherapy may contribute to its effectiveness in local control [77], and might similarly aid the release of immunogenic antigens triggering enhanced systemic immune responses [78]. But, mechanisms that release immunogenic antigens into the circulation might simultaneously permit the increased release of viable tumour cells into the circulation, demonstrating the conflict between pro- and anti-metastatic effects of radiotherapy. Further, hypoxia induced by sub-lethal tumour irradiation in a xenograft model actually increased metastasis compared to unirradiated tumours [79], while radiotherapy in patients with hepatocellular carcinoma seemed to enhance tumour progression outside the treatment field via induction of angiogenesis [80], adding further complexity to the extrapolation from biological observations to their final impact on metastasis risk.

The increasing range of photon delivery modalities with their accompanying variation in normal tissue irradiation may have implications for signalling between the tumour and surrounding stroma, vasculature and lymphatics. Radiation damage in non-target tissues, such as lung inflammation and fibrosis following breast tumour radiotherapy, may alter the risk of metastasis to these tissues [81]. However, since collateral damage to normal tissues scales with distance from the target volume, such sites might be at greater risk simply due to proximity to the primary tumour, complicating retrospective analysis of the locations of metastatic lesions. There is evidence that bone marrow-derived cells form a pre-metastatic niche prior to the arrival of tumour cells that can recruit and retain circulating tumour cells [82] in sites corresponding to the commonly observed metastatic profile of a given tumour. It is possible that radiation exposure of either the bone marrow or the pre-metastatic niches could alter this process, however it is unclear whether such effects would be pro- or anti-metastatic.

Co-culture of pancreatic cancer cells with gamma-irradiated stromal fibroblasts increases their invasiveness through secretion of paracrine signals [83], with alterations in the extracellular matrix responsible for increased invasiveness of breast tumour cells after irradiation of the basement membrane [84]. Irradiated tumours themselves may secrete signals that recruit tumour cells already in the circulation back to the primary tumour site [85]. Many more such radiation effects on the tissue microenvironment have been described, reviewed in [86], 
and may contribute (positively or negatively) to the incidence of metastasis from irradiated tumour sites, and each may be sensitive to the changes in irradiation parameters that accompany the various radiotherapy modalities. For example, experimental evidence that carbon ion [87] and proton irradiation [88] supresses angiogenic factors in non-transformed cells suggests a mechanism by which radiation quality could impact the receptiveness of surrounding tissues to pre-existing or incoming tumour cells.

\section{Radiation-Induced Changes in Surviving Tumour Cells}

At the time of von Essen's review, there was limited evidence supporting the proposed hypothesis 'direct alteration of tumour cells by irradiation.' Although radiation exposure can cause a wide range of changes within cells that can lead to a variety of responses and cell fates, reviewed in [89], radiobiology research over the past century has been dominated by two primary endpoints: cell death and mutation. These principal measures of radiation effect are driven by context, with radiation-induced cell death the most relevant metric for both treatment success and normal tissue complications in radiotherapy, while DNA mutations are assessed as the mediators of radiationinduced cancer risk. This convergence to ultimately express fractions of live versus dead cells, or mutant versus normal cells as the prime measures of radiation effect has meant that radiation-induced metabolic changes, geneexpression responses, or phenotypic changes such as motility, activation, proliferation and signalling are less-well understood, and were rarely regarded as primary outcomes of radiation exposure.

Yet as the context changes, so do the radiation-induced effects which become most relevant. With the increasing success of radiotherapy in controlling primary tumours, the effects radiation has on surviving tumour cells come to the fore when considering post-treatment secondary cancer/metastatic risk [90]. One caveat is the effect of selection, where radiation may not induce a phenotypic change, but it might indirectly result in a surviving population with a distinct phenotype from that which was predominant in the initial population. Indeed, radiationinduced selection may be the major mechanism underlying changes in tumour cell phenotype caused by radiotherapy [91]. This is key to the question as to whether radiation-induced cell death of sensitive subpopulations passively results in the selection of radioresistant tumour cells, or whether radiation actively promotes features of radioresistance [92]. An example of the later is radiotherapy-induced hypoxia [93] that alters the inherent radioresistance of the remaining tumour cell population, or the radiation-induced induction of cathepsin $\mathrm{S}$, a cysteine protease, in breast cancer cells which increases their radioresistance [94].

Where radiation eliminates or permanently incapacitates cells, either through direct or delayed cell death or senescence/differentiation, short-term observations in irradiated cell populations may not correspond to the 
changes observed in long-term survivors [95]. However, transient phenotypic changes may nonetheless influence metastatic risk where tumour cells are released during radiotherapy while still expressing a transient radiationinduced phenotype; where short-term responses aid inter-fraction recovery or proliferation; or, where radiationinduced changes in tumour cells permanently alter their surrounding microenvironment. This last case blurs the lines between radiation effects in tumour and non-tumour cells, with radiation-induced angiogenic signalling from tumour cells able to stimulate the local vasculature at the same time as radiation exposure has its own direct effects on the vasculature $[77,60]$. Interestingly, such complex interactions may differ with radiotherapy modalities, with carbon ion and proton irradiation both shown to suppress angiogenesis in irradiated tumour cells, unlike proangiogenic responses observed for photon irradiation [96,88].

It is also important to differentiate between radiation-induced phenotypic changes which are generalizable and repeatable, and changes due to stochastic radiation-induced mutations in surviving tumour cells. This also applies more generally to the variability of human cancers where, as shown in a study by Fujita et al. [97], panels of cell lines fell on a spectrum from radiation-induced to radiation-reduced invasiveness, with the genetic status of given tumours shown to alter their response to radiation [98]. There may not be a single answer as to whether a radiotherapy modality ultimately promotes or inhibits the metastatic properties of a tumour, with the result dependent on the nature of the patient's tumour.

Thus, it is necessary to consider what changes radiation might induce in tumour cells which will ultimately survive a course of radiotherapy treatment, or survive until being released as CTCs. The specifics of such changes are themselves likely to be dependent on the radiation exposure scenario, with repeated exposure to fractionated radiotherapy across several cellular generations potentially inducing different responses to a single high radiation dose, while increasing dose-per-fraction or decreasing inter-fraction time might decrease the viability of any tumour cells released as CTCs during the initial fractions of radiotherapy treatment [22]. The use of concomitant chemotherapy to radiosensitise tumour cells could reduce the risk of viable CTCs entering the bloodstream early during the course of radiotherapy, with some evidence of reduced distant-metastasis with concomitant cisplatin compared to radiotherapy alone [99], as well as a combination of cisplatin and a hypoxic radiosensitiser [100]. A meta-analysis of cervical cancer trials using both platinum and non-platinum based chemoradiotherapy [101] showed evidence of reduced metastatic risk and delayed metastatic interval, consistent with such a mechanism.

The discovery that sub-lethal gamma-irradiation of cultured malignant glioma cells increased features of motility, adhesion and cell-cell interactions to produce a more invasive phenotype, which was confirmed by increased 
invasiveness when implanted into mice [102], provided some of the first evidence for the ability of radiation to alter the metastatic properties of tumour cells. Shortly thereafter, similar findings in pancreatic tumour cell lines exposed to 3 - 10 Gy of gamma radiation showed increased invasiveness, similarly with evidence for upregulation of matrix metallo-proteinase (MMP) activity [103]. Yet already, these studies began to show that responses were not uniform, with responding and non-responding lines, and different outcomes between migration, motility and invasiveness which did not always correlate. The plethora of evidence which has since been accumulated in this area has been reviewed in detail [104,97]. Importantly, studies have since confirmed that these phenotypic changes (motility, invasiveness and MMP expression) exist in the long-term survivors after highdose irradiation [95].

Of great interest were findings that irradiation with protons or carbon ions did not induce the invasive phenotype observed with sub-lethal doses of photon irradiation [105,106], and unlike photons, inhibited MMP expression. Later work showed that although increased proliferation and invasiveness could be observed in some cell lines after X-ray irradiation, both were decreased in the same cells when exposed to carbon ion irradiation [107]. Interestingly, increasing the X-ray dose further showed similar decreases in proliferation and invasiveness to that observed with the heavy ions, suggesting hypo-fractionated irradiation may induce different responses. This is supported by recent work demonstrating a range of differences in the biological responses of lung cancer cells to stereotactic versus conventionally-fractionated radiotherapy doses [108]. Further work in medulloblastoma cell lines showed that both photon and carbon ion irradiation decreased motility and down-regulated MMP expression [109], showing again that pro-metastatic changes are not universal or strictly predicted by radiation quality, reviewed in [110]. Additional mechanisms underlying these changes have been discovered including changes in the actin cytoskeleton and stiffness [111,112]; increased integrin expression [113]; increased oncogene transcription [114]; and, increased secretion of lysyl oxidase [115]. Improved understanding of the mechanisms underlying these effects will help to determine which effects are most relevant to human radiotherapy scenarios.

The findings which have attracted the most attention have been those related to the ability of radiation to induce or promote epithelial-to-mesenchymal transition (EMT) in tumour cells, which was the subject of a recent comprehensive review by Lee et al. [116]. It has been unclear whether the EMT-like changes observed are due to the precocious induction of the spontaneous EMT observed in a variety of human cancers, or whether specific biological responses which overlap with spontaneous EMT are independently invoked. Whether the EMT/EMT- 
like changes are independent of the motility, migration and invasion phenotypes mentioned above, or whether they represent various aspects of a broader program is also yet to be resolved.

Key steps forward in this area have come from experiments showing that irradiated tumour cells show not only changes in EMT-markers, but functional changes that demonstrate the acquisition of cancer stem-cell properties [117,118]. Cancer stem-cells are known to be inherently radioresistant, due in part to an enhanced DNA damage response $[119,120]$. Radiation has been shown to induce gene expression changes similar to patterns observed in embryonic stem cells [121], and irradiated breast tumour cells show complex temporal changes in the expression of EMT regulators such as Bmi-1, vimentin and E-cadherin [122], with initial decreases in invasiveness followed by gradual elevations to above-baseline levels. Changes in chromatin configuration have emerged as essential to EMT-related transcription factor regulation $[123,124]$, but they are still to be fully characterised. Weyemi et al. discovered that down-regulation of $\mathrm{H} 2 \mathrm{AX}$, a histone variant involved in DNA repair [125], can regulate EMT and its reversal by changing chromatin configuration and by controlling the critical EMT-associated transcription factors Slug and ZEB1 in colon carcinoma cells [126]. A further report in human mammary MCF10A cells [127] validated the important role of H2AX levels in the tissue-specific regulation of EMT (Twist1/Slug for breast; ZEB1/Slug for colon), with the in vitro and in vivo evidence reviewed in [128]. Chromatin changes in the wake of tumour cell irradiation present an attractive link between radiotherapy and the induction of EMT, but further experiments are needed to characterise these connections.

Models for tracking metastasis and EMT changes in vivo following radiotherapy provide a method to further explore the nature of the phenomenon [129], including experimental systems that allow in vivo testing of stereotactic radiotherapy regimens [52]. Two different studies showing the induction of EMT after fractionated radiotherapy $[130,131]$ have demonstrated the relevance of the effect to routine human cancer therapy, with important implications for disease monitoring where radiation exposure can depress tumour markers being used as clinical biomarkers. Further experiments have implicated yet more mechanistic links, including TGF- $\beta$ expression [132] and signalling through the bioactive gas hydrogen sulphide [133], reviewed in [134]. It should be noted that radiation-induction of EMT is also not universally observed [135], with evidence that the cell culture systems can interfere with altered morphology associated with EMT, highlighting the need for caution in generalising these phenomena from the specific observations to recommendations for cancer therapy strategies. The range of radiation-induced biological effects in tumour cells continues to grow with observations of altered antigen expression in tumour cells [136] and changes in differentiation [137]. Ever-expanding 'omics' techniques 
will no doubt increase the number of biological effects found to be induced (or suppressed) in irradiated tumour cells into the future.

\section{Potential for Intervention}

Given our current limited understanding of the precise mechanisms which might facilitate radiation-induced metastasis, it is difficult to nominate general interventions which would be of certain benefit in reducing the risk of distant metastasis following radiotherapy. For instance, although the immune system has been shown to play a critical role in eliminating disseminated tumour cells [138], it is unclear whether promoting a generic proinflammatory environment would be beneficial overall given counteracting effects on normal tissues which might promote a receptive environment for a metastatic niche [81]. Yet, better understanding of specific immune pathways allows for targeted approaches, such as following radiotherapy (known to up-regulate the expression of the immune suppressive PD-L1 in tumour cells [139]) with a PD-L1 inhibitor, which prevented and delayed metastasis [140]. This paradigm begins to blur the line between immunotherapy as a secondary compliment to curative radiotherapy, and radiotherapy as an adjuvant prior to curative immunotherapy [141]. Such an approach is the use of pre-surgical neoadjuvant radiotherapy to stimulate anti-tumour immune responses [142]. Alternative proposals include the use of accelerated radiotherapy to reduce the viability of CTCs released at the start of radiotherapy [5], or the use of thrombolytic agents to destabilise CTC clusters [143]. The design of such specific interventions relies on the capture of quality data during clinical trials, such that local failure can be clearly differentiated from distant metastasis, and the timing and location of metastasis can be interrogated in more detail. These data can form the basis of sophisticated models that allow both the testing of specific hypotheses [144,145], and the discovery of new relationships between radiotherapy treatment and metastasis that can provide new targets for intervention.

\section{Conclusion}

Radiation therapy clearly reduces the risk of metastasis compared to administering no treatment. The question at stake is whether the efficacy of the treatment, which inhibits metastasis primary through the killing of tumour cells in the treatment volume, is counteracted (to a variable extent) by radiation-induced effects which might disseminate viable tumour cells, have systemic pro-metastatic effects through signalling, and/or alter the phenotype of the cells which survive the radiation treatment. Any measurement of metastasis rates in a radiotherapy clinical trial will represent the net of the desired anti-metastatic effect and any undesirable pro- 
metastatic effects, so it is not a simple task to separate these potentially conflicting processes. Improvements in long-term treatment success could be made both through further enhancing tumour cell kill and local control, but also, through preventing any radiotherapy-induced metastatic mechanisms, which may be specific to the different treatment modalities. Comparisons of distant metastasis-free survival rates between radiotherapy treatment modalities may not immediately reveal any pro- or anti-metastatic events that vary with irradiation parameters such as dose, dose-rate or radiation quality, but basic radiobiology research and improving animal models are beginning to uncover the complexity across the tumour microenvironment. Further understanding the variables that contribute to these treatment-induced metastasis risks is key to designing appropriate prevention and mitigation strategies, and identifying modalities which may have inherent advantages for preventing distant relapse. 


\section{FIGURE CAPTIONS}

\section{Figure 1 Key Radiation Exposure Parameters Defining Modern Radiation Therapy Modalities}

Compared to conventional radiotherapy (photons, $5 \times 2$ Gy fractions per week) many modern radiation therapy modalities change one or more exposure parameters with the goals of: improving local control, sparing normal tissue, improving patient experience (shorter overall treatment times) and/or reducing the risk of radiation-induced second malignancies. The term 'novel photon modalities' includes a variety of methods including, but not limited to: 3D-conformal radiotherapy, intensity-modulated radiotherapy, volumetric modulated arc therapy and flattening filter-free radiotherapy.

\section{Figure 2 Mechanisms of Post-Treatment Distant Metastasis}

In some clinical cases, although imaging after treatment of a localised primary tumour (A, arrow) shows complete local control, disseminated metastases can be observed (B, star) several months after the completion of treatment, which were not evident in prior imaging (in mediastinum, lung, liver and vertebrae). There are several explanations for such phenomena $(\mathrm{C})$ : the first is that spontaneous metastasis from the primary tumour occurred prior to treatment, but were below the level of detection, so-called occult micro-metastases; another explanation is that spontaneous metastasis from the primary tumour occurred in spite of radiation treatment; however, the possibility is now being actively explored that radiation treatment might play a role in cases of rapid dissemination, even while simultaneously achieving complete local control.

\section{Figure 3 Radiation Effects on the Tumour Microenvironment}

Radiation exposure has a variety of effects on tumours and their local environment. (1) Radiation causes extensive tumour cell death. (2) Irradiated tumours and surrounding stroma may suffer physical disruption. (3) Radiation can damage the tumour vasculature. (4) The disturbance of the tumour and vasculature can result in the release of tumour cells into the circulation. (5) Radiation can have direct effects on surviving tumour cells, altering their phenotype, such as altered migration, invasiveness, radioresistance, hypoxia, epithelial-to-mesenchymal transition, and stemness. (6) Radiation selects for pre-existing radioresistant cells and cancer stem cells which now represent more of the total tumour cell population. (7) Radiation can alter the phenotype of irradiated stroma. (8) Radiation can induce signalling from the surrounding stroma into the local area and into the circulation. (9) Irradiated tumour cells can also release signals into the local area and into the circulation. Signalling molecules implicated in radiation-induced metastasis include but are not limited to VEGF, LOX, HIF-1, EGFR and TGF- $\beta$. 


\section{REFERENCES}

1. Kaplan HS, Mury ED (1949) The effect of local roentgen irradiation on the biological behavior of a transplantable mouse carcinoma; increased frequency of pulmonary metastasis. Journal of the National Cancer Institute 9 (5-6):407-413

2. Ebos J (2015) Prodding the Beast: Assessing the Impact of Treatment-Induced Metastasis. Cancer Research 75 (17):34273435. doi:10.1158/0008-5472.CAN-15-0308

3. von Essen CF (1991) Radiation enhancement of metastasis: a review. Clinical \& experimental metastasis 9 (2):77-104

4. Martin OA, Anderson RL, Russell PA, Cox AR, Ivashkevich A, Swierczak A, Doherty JP, Jacobs D, Smith J, Siva S, Daly PE, Ball DL, Martin RF, MacManus MP (2014) Mobilization of Viable Tumor Cells Into the Circulation During Radiation Therapy. International Journal of Radiation Oncology*Biology*Physics 88 (2):395-403. doi:10.1016/j.ijrobp.2013.10.033

5. Martin OA, Anderson RL, Narayan K, MacManus MP (2017) Does the mobilization of circulating tumour cells during cancer therapy cause metastasis? Nature Reviews Clinical Oncology 14

6. Baskar R, Lee K, Yeo R, Yeoh K-W (2012) Cancer and Radiation Therapy: Current Advances and Future Directions. International Journal of Medical Sciences 9 (3):193-199. doi:10.7150/ijms.3635

7. Bucci KM, Bevan A, Roach M (2005) Advances in Radiation Therapy: Conventional to 3D, to IMRT, to 4D, and Beyond. CA: A Cancer Journal for Clinicians 55 (2):117-134. doi:10.3322/canjclin.55.2.117

8. Allison RR, Patel RM, McLawhorn RA (2014) Radiation oncology: physics advances that minimize morbidity. Future Oncology 10 (15):2329-2344. doi:10.2217/fon.14.176

9. Murray LJ, Thompson CM, Lilley J, Cosgrove V, Franks K, Sebag-Montefiore D, Henry AM (2015) Radiation-induced second primary cancer risks from modern external beam radiotherapy for early prostate cancer: impact of stereotactic ablative radiotherapy (SABR), volumetric modulated arc therapy (VMAT) and flattening filter free (FFF) radiotherapy. Physics in medicine and biology 60 (3):1237-1257. doi:10.1088/0031-9155/60/3/1237

10. Irazola L, Ortiz-Seidel M, Velázquez S, García-Hernández M, Terrón J, Sánchez-Nieto B, Romero-Expósito M, Roselló J, Sánchez-Doblado F (2016) EP-1613: Comparison of peripheral doses associated to SBRT, VMAT, IMRT, FFF and 3DCRT plans for lung cancer. Radiotherapy and Oncology 119. doi:10.1016/s0167-8140(16)32864-x

11. Hall EJ, Wuu C-S (2003) Radiation-induced second cancers: the impact of 3D-CRT and IMRT. International Journal of Radiation Oncology*Biology*Physics 56 (1):83-88. doi:10.1016/S0360-3016(03)00073-7

12. Lievens Y, Nulens A, Gaber M, Defraene G, Wever W, Stroobants S, den Heuvel F, Group L (2011) Intensity-Modulated Radiotherapy for Locally Advanced Non-Small-Cell Lung Cancer: A Dose-Escalation Planning Study. International Journal of Radiation Oncology*Biology*Physics 80 (1):306-313. doi:10.1016/j.ijrobp.2010.06.025

13. Guckenberger M, Kavanagh A, Partridge M (2012) Combining advanced radiotherapy technologies to maximize safety and tumor control probability in stage III non-small cell lung cancer. Strahlentherapie und Onkologie 188 (10):894-900. doi:10.1007/s00066-012-0161-9

14. Chang AJ, Bradley JD (2010) Clinical Perspectives on Dose Escalation for Non-Small-Cell Lung Cancer. Clinical Lung Cancer 11 (5):299-302. doi:10.3816/clc.2010.n.037

15. Murray D, McBride WH, Schwartz JL (2014) Radiation Biology in the Context of Changing Patterns of Radiotherapy. Radiation Research 182 (3):259-272. doi:10.1667/RR13740.1

16. Hall EJ, Giaccia AJ (2012) Radiobiology for the Radiologist. 7th edn. Wolters Kluwer Health/Lippincott Williams \& Wilkins, Philadelphia, PA

17. Coutard H (1934) PRINCIPLES OF X RAY THERAPY OF MALIGNANT DISEASES. The Lancet 224 (5784):1-8. doi:10.1016/S0140-6736(00)90085-0

18. Nahum AE (2015) The Radiobiology of Hypofractionation. Clinical Oncology 27 (5):260-269. doi:10.1016/j.clon.2015.02.001

19. Fowler JF, Welsh JS, Howard SP (2004) Loss of biological effect in prolonged fraction delivery. International Journal of Radiation Oncology*Biology*Physics 59 (1):242-249. doi:10.1016/j.ijrobp.2004.01.004

20. Joiner MC, Mogili N, Marples B, Burmeister J (2010) Significant dose can be lost by extended delivery times in IMRT with $x$ rays but not high-LET radiations. Medical Physics 37 (6):2457-2465. doi:10.1118/1.3425792

21. Lyhne NM, Primdahl H, Kristensen CA, Andersen E, Johansen J, Andersen LJ, Evensen J, Mortensen HR, Overgaard J (2015) The DAHANCA 6 randomized trial: Effect of 6 vs 5 weekly fractions of radiotherapy in patients with glottic squamous cell carcinoma. Radiotherapy and Oncology 117 (1):91-98. doi:10.1016/j.radonc.2015.07.004

22. Saunders M, Dische S, Barrett A, Harvey A, Griffiths G, Palmar M (1999) Continuous, hyperfractionated, accelerated radiotherapy (CHART) versus conventional radiotherapy in non-small cell lung cancer: mature data from the randomised multicentre trial. CHART Steering committee. Radiotherapy and oncology : journal of the European Society for Therapeutic Radiology and Oncology 52 (2):137-148 
23. Saunders M, Dische S, Barrett A, Harvey A, Gibson D, Parmar M (1997) Continuous hyperfractionated accelerated radiotherapy (CHART) versus conventional radiotherapy in non-small-cell lung cancer: a randomised multicentre trial. CHART Steering Committee. Lancet 350 (9072):161-165

24. Thomas EM, Popple RA, Prendergast BM, Clark GM, Dobelbower MC, Fiveash JB (2013) Effects of flattening filter-free and volumetric-modulated arc therapy delivery on treatment efficiency. Journal of Applied Clinical Medical Physics 14 (6):155-166. doi:10.1120/jacmp.v14i6.4328

25. Spratt DE, Wu AJ, Adeseye V, Din SU, Shaikh F, Woo KM, Zhang Z, Foster A, Rosenzweig KE, Gewanter R, Huang J, Rimner A (2016) Recurrence Patterns and Second Primary Lung Cancers After Stereotactic Body Radiation Therapy for EarlyStage Non-Small-Cell Lung Cancer: Implications for Surveillance. Clinical Lung Cancer 17 (3):177-18300. doi:10.1016/j.cllc.2015.09.006

26. Verstegen NE, Lagerwaard FJ, Hashemi S, Dahele M, Slotman BJ, Senan S (2015) Patterns of Disease Recurrence after SABR for Early Stage Non-Small-Cell Lung Cancer: Optimizing Follow-Up Schedules for Salvage Therapy. Journal of Thoracic Oncology 10 (8):1195-1200. doi:10.1097/jto.0000000000000576

27. van den Berg LL, Klinkenberg TJ, Groen H, Widder J (2015) Patterns of Recurrence and Survival after Surgery or Stereotactic Radiotherapy for Early Stage NSCLC. Journal of Thoracic Oncology 10 (5):826-831. doi:10.1097/jto.0000000000000483

28. Kim M-S, Kim W, Park I, Kim H, Lee E, Jung J-H, Cho L, Song CW (2015) Radiobiological mechanisms of stereotactic body radiation therapy and stereotactic radiation surgery. Radiation Oncology Journal 33 (4):265-275. doi:10.3857/roj.2015.33.4.265

29. Brown MJ, Carlson DJ, Brenner DJ (2014) The Tumor Radiobiology of SRS and SBRT: Are More Than the 5 Rs Involved? International Journal of Radiation Oncology*Biology*Physics 88 (2):254-262. doi:10.1016/j.ijrobp.2013.07.022

30. Shuryak I, Carlson DJ, Brown MJ, Brenner DJ (2015) High-dose and fractionation effects in stereotactic radiation therapy: Analysis of tumor control data from 2965 patients. Radiotherapy and Oncology 115 (3):327-334. doi:10.1016/j.radonc.2015.05.013

31. Girdhani S, Sachs R, Hlatky L (2013) Biological Effects of Proton Radiation: What We Know and Don't Know. Radiation research 181 (6):257-272. doi:10.1667/RR2839.1

32. Durante M, Orecchia R, Loeffler JS (2017) Charged-particle therapy in cancer: clinical uses and future perspectives. Nature Reviews Clinical Oncology. doi:10.1038/nrclinonc.2017.30

33. Paganetti H (2014) Relative biological effectiveness (RBE) values for proton beam therapy. Variations as a function of biological endpoint, dose, and linear energy transfer. Physics in Medicine and Biology 59 (22). doi:10.1088/00319155/59/22/R419

34. Hamada N, Imaoka T, Masunaga S-i, Ogata T, Okayasu R, Takahashi A, Kato TA, Kobayashi Y, Ohnishi T, Ono K, Shimada Y, Teshima T (2010) Recent advances in the biology of heavy-ion cancer therapy. Journal of radiation research 51 (4):365-383

35. Yoshioka Y, Suzuki O, Otani Y, Yoshida K, Nose T, Ogawa K (2014) High-dose-rate brachytherapy as monotherapy for prostate cancer: technique, rationale and perspective. Journal of Contemporary Brachytherapy 6 (1):91-98. doi:10.5114/jcb.2014.42026

36. Lohse I, Lang S, Hrbacek J, Scheidegger S, Bodis S, Macedo NS, Feng J, Lütolf UM, Zaugg K (2011) Effect of high dose per pulse flattening filter-free beams on cancer cell survival. Radiotherapy and Oncology 101 (1):226-232. doi:10.1016/j.radonc.2011.05.072

37. Michaelidesová A, Vachelová J, Puchalska M, Brabcová K, Vondráček V, Sihver L, Davídková M (2017) Relative biological effectiveness in a proton spread-out Bragg peak formed by pencil beam scanning mode. Australasian Physical \& Engineering Sciences in Medicine:1-10. doi:10.1007/s13246-017-0540-8

38. Schüler E, Trovati S, King G, Lartey F, Rafat M, Villegas M, Praxel JA, Loo BW, Maxim PG (2017) Experimental Platform for Ultra-high Dose Rate FLASH Irradiation of Small Animals Using a Clinical Linear Accelerator. International Journal of Radiation Oncology*Biology*Physics 97 (1):195-203. doi:10.1016/j.ijrobp.2016.09.018

39. Bouchet A, Lemasson B, Duc G, Maisin C, Bräuer-Krisch E, Siegbahn E, Renaud L, Khalil E, Rémy C, Poillot C, Bravin A, Laissue JA, Barbier EL, Serduc R (2010) Preferential Effect of Synchrotron Microbeam Radiation Therapy on Intracerebral 9L Gliosarcoma Vascular Networks. International Journal of Radiation Oncology*Biology*Physics 78 (5):1503-1512. doi:10.1016/j.ijrobp.2010.06.021

40. Régnard P, Bräuer-Krisch E, Troprès I, Keyriläinen J, Bravin A, Duc G (2008) Enhancement of survival of 9L gliosarcoma bearing rats following intracerebral delivery of drugs in combination with microbeam radiation therapy. European Journal of Radiology 68 (3). doi:10.1016/j.ejrad.2008.04.049

41. Smyth LML, Senthi S, Crosbie JC, Rogers PAW (2016) The normal tissue effects of microbeam radiotherapy: What do we know, and what do we need to know to plan a human clinical trial? International Journal of Radiation Biology 92 (6):302311. doi:10.3109/09553002.2016.1154217 
42. Rud A, Boye K, Fodstad Ø, Juell S, Jørgensen LH, Solberg S, Helland Å, Brustugun O, Mælandsmo G (2016) Detection of disseminated tumor cells in lymph nodes from patients with early stage non-small cell lung cancer. Diagnostic Pathology 11 (1):50. doi:10.1186/s13000-016-0504-4

43. Maruyama R, Sugio K, Mitsudomi T, Saitoh G, Ishida T, Sugimachi K (1997) Relationship between early recurrence and micrometastases in the lymph nodes of patients with stage I non-small-cell lung cancer. The Journal of Thoracic and Cardiovascular Surgery 114 (4):535-543. doi:10.1016/S0022-5223(97)70041-2

44. Osaki T, Oyama T, Gu C-D, Yamashita T, So T, Takenoyama M, Sugio K, Yasumoto K (2002) Prognostic impact of micrometastatic tumor cells in the lymph nodes and bone marrow of patients with completely resected stage I non-small-cell lung cancer. Journal of clinical oncology : official journal of the American Society of Clinical Oncology 20 (13):2930-2936. doi:10.1200/jco.2002.11.011

45. Bouchard G, Therriault H, Bujold R, Saucier C, Paquette B (2017) Induction of interleukin-1 $\beta$ by mouse mammary tumor irradiation promotes triple negative breast cancer cells invasion and metastasis development. International Journal of Radiation Biology:1-38. doi:10.1080/09553002.2017.1270471

46. Woods GM, Bondra K, Chronowski C, Leasure J, Singh M, Hensley L, Cripe TP, Chakravarti A, Houghton PJ (2015) Radiation therapy may increase metastatic potential in alveolar rhabdomyosarcoma. Pediatric Blood \& Cancer 62 (9):15501554. doi: $10.1002 /$ pbc. 25516

47. Janni WJ, Rack B, Terstappen L, Pierga J-Y, Taran F-A, Fehm T, Hall C, de Groot MR, Bidard F-C, Friedl T, Fasching PA, Brucker SY, Pantel K, Lucci A (2016) Pooled Analysis of the Prognostic Relevance of Circulating Tumor Cells in Primary Breast Cancer. Clinical Cancer Research 22 (10):2583-2593. doi:10.1158/1078-0432.CCR-15-1603

48. Suesskind D, Ulmer A, Schiebel U, Fierlbeck G, Spitzer B, Spitzer MS, Bartz-Schmidt KU, Grisanti S (2011) Circulating melanoma cells in peripheral blood of patients with uveal melanoma before and after different therapies and association with prognostic parameters: a pilot study. Acta Ophthalmologica 89 (1):17-24. doi:10.1111/j.1755-3768.2009.01617.x

49. Yu N, Zhou J, Cui F, Tang X (2015) Circulating Tumor Cells in Lung Cancer: Detection Methods and Clinical Applications. Lung 193 (2). doi:10.1007/s00408-015-9697-7

50. Dorsey JF, Kao GD, MacArthur KM, Ju M, Steinmetz D, Wileyto PE, Simone CB, Hahn SM (2015) Tracking viable circulating tumor cells (CTCs) in the peripheral blood of non-small cell lung cancer (NSCLC) patients undergoing definitive radiation therapy: Pilot study results. Cancer 121 (1):139-149. doi:10.1002/cncr.28975

51. Masunaga S, Matsumoto Y, Kashino G, Hirayama R, Liu Y, Tanaka H, Sakurai Y, Suzuki M, Kinashi Y, Maruhashi A, Ono K (2010) Significance of manipulating tumour hypoxia and radiation dose rate in terms of local tumour response and lung metastatic potential, referring to the response of quiescent cell populations. The British Journal of Radiology 83 (993):776784. doi:10.1259/bjr/57015642

52. Zhang Z, Wodzak M, Belzile O, Zhou H, Sishc B, Yan H, Stojadinovic S, Mason RP, Brekken RA, Chopra R, Story MD, Timmerman R, Saha D (2016) Effective Rat Lung Tumor Model for Stereotactic Body Radiation Therapy. Radiation research 185 (6):616-622. doi:10.1667/RR14382.1

53. Tharmalingham H, Hoskin PJ (2017) The changing role of radiation therapy in the management of oligometastatic disease. Technical Innovations \& Patient Support in Radiation Oncology 1:13-15. doi:10.1016/j.tipsro.2017.01.001

54. Blyth BJ, Sykes PJ (2011) Radiation-Induced Bystander Effects: What Are They, and How Relevant Are They to Human Radiation Exposures? Radiation Research 181 (6):139-157. doi:10.1667/rr2548.1

55. Sprung CN, Ivashkevich A, Forrester HB, Redon CE, Georgakilas A, Martin OA (2015) Oxidative DNA damage caused by inflammation may link to stress-induced non-targeted effects. Cancer letters 356 (1):72-81. doi:10.1016/j.canlet.2013.09.008

56. Hong M (2014) Heavy ion-related bystander effects. Rendiconti Lincei. doi:10.1007/s12210-013-0285-6

57. Revesz L (1958) Effect of lethally damaged tumor cells upon the development of admixed viable cells. Journal of the National Cancer Institute 20 (6):1157-1186

58. van den Brenk HA, Crowe MC, Stone MG (1977) Reactions of the tumour bed to lethally irradiated tumour cells, and the Révész effect. British Journal of Cancer 36 (1):94-104. doi:10.1038/bjc.1977.159

59. Kuonen F, Secondini C, Rüegg C (2012) Molecular Pathways: Emerging Pathways Mediating Growth, Invasion, and Metastasis of Tumors Progressing in an Irradiated Microenvironment. Clinical Cancer Research 18 (19):5196-5202. doi:10.1158/1078-0432.ccr-11-1758

60. Rüegg C, Monnier Y, Kuonen F, Imaizumi N (2011) Radiation-induced modifications of the tumor microenvironment promote metastasis. Bulletin du cancer 98 (6):47-57. doi:10.1684/bdc.2011.1372

61. Vala I, Martins LR, Imaizumi N, Nunes RJ, Rino J, Kuonen F, Carvalho LM, Rüegg C, Grillo I, Barata J, Mareel M, Santos S (2010) Low Doses of Ionizing Radiation Promote Tumor Growth and Metastasis by Enhancing Angiogenesis. PLoS ONE 5 (6). doi:10.1371/journal.pone.0011222 
62. Yarnold J (2009) Early and locally advanced breast cancer: diagnosis and treatment National Institute for Health and Clinical Excellence guideline 2009. Clin Oncol (R Coll Radiol) 21 (3):159-160. doi:10.1016/j.clon.2008.12.008

63. Fisher B, Anderson S, Bryant J, Margolese RG, Deutsch M, Fisher ER, Jeong JH, Wolmark N (2002) Twenty-year followup of a randomized trial comparing total mastectomy, lumpectomy, and lumpectomy plus irradiation for the treatment of invasive breast cancer. The New England journal of medicine 347 (16):1233-1241. doi:10.1056/NEJMoa022152

64. Siva S, Lobachevsky P, MacManus MP, Kron T, Mo ller A, Lobb RJ, Ventura J, Best N, Smith J, Ball D, Martin OA (2016) Radiotherapy for Non-Small Cell Lung Cancer Induces DNA Damage Response in Both Irradiated and Out-of-field Normal Tissues. Clinical Cancer Research 22 (19):4817-4826. doi:10.1158/1078-0432.ccr-16-0138

65. Kaminski JM, Shinohara E, Summers J, Niermann KJ, Morimoto A, Brousal J (2005) The controversial abscopal effect. Cancer Treatment Reviews 31 (3):159-172. doi:10.1016/j.ctrv.2005.03.004

66. Siva S, MacManus MP, Martin RF, Martin OA (2015) Abscopal effects of radiation therapy: A clinical review for the radiobiologist. Cancer letters 356 (1):82-90. doi:10.1016/j.canlet.2013.09.018

67. Camphausen K, Moses MA, Beecken WD, Khan MK, Folkman J, O'Reilly MS (2001) Radiation therapy to a primary tumor accelerates metastatic growth in mice. Cancer research 61 (5):2207-2211

68. Redon CE, Dickey JS, Nakamura AJ, Kareva IG, Naf D, Nowsheen S, Kryston TB, Bonner WM, Georgakilas AG, Sedelnikova OA (2010) Tumors induce complex DNA damage in distant proliferative tissues in vivo. Proceedings of the National Academy of Sciences 107 (42):17992-17997. doi:10.1073/pnas.1008260107

69. Biswas S, Guix M, Rinehart C, Dugger TC, Chytil A, Moses HL, Freeman ML, Arteaga CL (2007) Inhibition of TGF- $\beta$ with neutralizing antibodies prevents radiation-induced acceleration of metastatic cancer progression. Journal of Clinical Investigation 117 (5):1305-1313. doi:10.1172/jci30740

70. Wu Y, Muldoon LL, Dickey D, Lewin SJ, Varallyay CG, Neuwelt EA (2009) Cyclophosphamide Enhances Human Tumor Growth in Nude Rat Xenografted Tumor Models. Neoplasia 11 (2):187-195. doi:10.1593/neo.81352

71. Yamauchi K, Yang M, Hayashi K, Jiang P, Yamamoto N, Tsuchiya H, Tomita K, Moossa AR, Bouvet M, Hoffman RM (2008) Induction of Cancer Metastasis by Cyclophosphamide Pretreatment of Host Mice: An Opposite Effect of Chemotherapy. Cancer Research 68 (2):516-520. doi:10.1158/0008-5472.can-07-3063

72. Demaria S, Golden EB, Formenti SC (2015) Role of Local Radiation Therapy in Cancer Immunotherapy. JAMA Oncology 1 (9):1325-1332. doi:10.1001/jamaoncol.2015.2756

73. Sprung CN, Forrester HB, Siva S, Martin OA (2015) Immunological markers that predict radiation toxicity. Cancer Letters 368 (2):191-197. doi:10.1016/j.canlet.2015.01.045

74. Matsunaga A, Ueda Y, Yamada S, Harada Y, Shimada H, Hasegawa M, Tsujii H, Ochiai T, Yonemitsu Y (2010) Carbonion beam treatment induces systemic antitumor immunity against murine squamous cell carcinoma. Cancer 116 (15):37403748. doi:10.1002/cncr.25134

75. Durante M, Brenner DJ, Formenti SC (2016) Does Heavy Ion Therapy Work Through the Immune System? International Journal of Radiation Oncology*Biology*Physics 96 (5):934-936. doi:10.1016/j.ijrobp.2016.08.037

76. Gameiro SR, Malamas AS, Bernstein MB, Tsang KY, Vassantachart A, Sahoo N, Tailor R, Pidikiti R, Guha CP, Hahn SM, Krishnan S, Hodge JW (2016) Tumor Cells Surviving Exposure to Proton or Photon Radiation Share a Common Immunogenic Modulation Signature, Rendering Them More Sensitive to T Cell-Mediated Killing. International Journal of Radiation Oncology*Biology*Physics 95 (1):120-130. doi:10.1016/j.ijrobp.2016.02.022

77. Song CW, Kim M-S, Cho CL, Dusenbery K, Sperduto PW (2014) Radiobiological basis of SBRT and SRS. International Journal of Clinical Oncology 19 (4):570-578. doi:10.1007/s10147-014-0717-z

78. Kim RK, Cui YH, Yoo KC, Kim IG, Lee M, Choi Y, Suh Y, Lee SJ (2015) Radiation promotes malignant phenotypes through SRC in breast cancer cells. Cancer Science 106 (1):78-85. doi:10.1111/cas.12574

79. Rofstad EK, Mathiesen B, Galappathi K (2004) Increased metastatic dissemination in human melanoma xenografts after subcurative radiation treatment: radiation-induced increase in fraction of hypoxic cells and hypoxia-induced up-regulation of urokinase-type plasminogen activator receptor. Cancer research 64 (1):13-18

80. Chung Y-L, Jian J, Cheng S, Tsai S, Chuang VP, Soong T, Lin Y-M, Horng C-F (2006) Sublethal Irradiation Induces Vascular Endothelial Growth Factor and Promotes Growth of Hepatoma Cells: Implications for Radiotherapy of Hepatocellular Carcinoma. Clinical Cancer Research 12 (9):2706-2715. doi:10.1158/1078-0432.CCR-05-2721

81. Feys L, Descamps B, Vanhove C, Vral A, Veldeman L, Vermeulen S, De Wagter C, Bracke M, De Wever O (2015) Radiation-induced lung damage promotes breast cancer lung-metastasis through CXCR4 signaling. Oncotarget 6 (29):2661526632. doi:10.18632/oncotarget.5666

82. Kaplan RN, Riba RD, Zacharoulis S, Bramley AH, Vincent L, Costa C, MacDonald DD, Jin DK, Shido K, Kerns SA, Zhu Z, Hicklin D, Wu Y, Port JL, Altorki N, Port ER, Ruggero D, Shmelkov SV, Jensen KK, Rafii S, Lyden D (2005) VEGFR1positive haematopoietic bone marrow progenitors initiate the pre-metastatic niche. Nature 438 (7069):820-827. doi:10.1038/nature04186 
83. Ohuchida K, Mizumoto K, Murakami M, Qian L-W, Sato N, Nagai E, Matsumoto K, Nakamura T, Tanaka M (2004) Radiation to Stromal Fibroblasts Increases Invasiveness of Pancreatic Cancer Cells through Tumor-Stromal Interactions. Cancer Research 64 (9):3215-3222. doi:10.1158/0008-5472.CAN-03-2464

84. Paquette B, Baptiste C, Therriault H, Arguin G, Plouffe B, Lemay R (2007) In vitro irradiation of basement membrane enhances the invasiveness of breast cancer cells. British Journal of Cancer 97 (11):1505-1512. doi:10.1038/sj.bjc.6604072

85. Vilalta M, Rafat M, Giaccia AJ, Graves EE (2014) Recruitment of Circulating Breast Cancer Cells Is Stimulated by Radiotherapy. Cell Reports 8 (2):402-409. doi:10.1016/j.celrep.2014.06.011

86. Leroi N, Lallemand F, Coucke P, Noel A, Martinive P (2016) Impacts of Ionizing Radiation on the Different Compartments of the Tumor Microenvironment. Frontiers in Pharmacology 7:78. doi:10.3389/fphar.2016.00078

87. Takahashi Y, Teshima T, Kawaguchi N, Hamada Y, Mori S, Madachi A, Ikeda S, Mizuno H, Ogata T, Nojima K, Furusawa Y, Matsuura N (2003) Heavy ion irradiation inhibits in vitro angiogenesis even at sublethal dose. Cancer research 63 (14):42534257

88. Girdhani S, Lamont C, Hahnfeldt P, Abdollahi A, Hlatky L (2012) Proton Irradiation Suppresses Angiogenic Genes and Impairs Cell Invasion and Tumor Growth. Radiation Research 178 (1). doi:10.1667/RR2724.1

89. Baskar R, Dai J, Wenlong N, Yeo R, Yeoh K-W (2014) Biological response of cancer cells to radiation treatment. Frontiers in Molecular Biosciences 1:24. doi:10.3389/fmolb.2014.00024

90. Martin OA, Yin X, Forrester HB, Sprung CN, Martin RF (2016) Potential strategies to ameliorate risk of radiotherapyinduced second malignant neoplasms. Seminars in Cancer Biology 37:65-76. doi:10.1016/j.semcancer.2015.12.003

91. McDermott N, Meunier A, Mooney B, Nortey G, Hernandez C, Hurley S, Lynam-Lennon N, Barsoom SH, Bowman KJ, Marples B, Jones GDD, Marignol L (2016) Fractionated radiation exposure amplifies the radioresistant nature of prostate cancer cells. Scientific Reports 6 (1):34796. doi:10.1038/srep34796

92. Pisco AO, Huang S (2015) Non-genetic cancer cell plasticity and therapy-induced stemness in tumour relapse: 'What does not kill me strengthens me'. British Journal of Cancer 112 (11):1725-1732. doi:10.1038/bjc.2015.146

93. Gong C, Gu R, Jin H, Sun Y, Li Z, Chen J, Wu G (2016) Lysyl oxidase mediates hypoxia-induced radioresistance in nonsmall cell lung cancer A549 cells. Experimental Biology and Medicine 241 (4):387-395. doi:10.1177/1535370215609694

94. Seo H, Bae S, Lee YS (2009) Radiation-induced cathepsin S is involved in radioresistance. International Journal of Cancer 124 (8):1794-1801. doi:10.1002/ijc.24095

95. Tsutsumi K, Tsuda M, Yazawa N, Nakamura H, Ishihara S, Haga H, Yasuda M, Yamazaki R, Shirato H, Kawaguchi H, Nishioka T, Ohba Y (2009) Increased Motility and Invasiveness in Tumor Cells That Survive 10 Gy Irradiation. Cell Structure and Function 34 (2):89-96. doi:10.1247/csf.09006

96. Kamlah F, Hänze J, Arenz A, Seay U, Hasan D, Juricko J, Bischoff B, Gottschald OR, Fournier C, Taucher-Scholz G, Scholz M, Seeger W, Engenhart-Cabillic R, Rose F (2011) Comparison of the Effects of Carbon Ion and Photon Irradiation on the Angiogenic Response in Human Lung Adenocarcinoma Cells. International Journal of Radiation Oncology*Biology*Physics 80 (5):1541-1549. doi:10.1016/j.ijrobp.2011.03.033

97. Fujita M, Yamada S, Imai T (2015) Irradiation induces diverse changes in invasive potential in cancer cell lines. Seminars in Cancer Biology 35:45-52. doi:10.1016/j.semcancer.2015.09.003

98. Park C-M, Park M-J, Kwak H-J, Lee H-C, Kim M-S, Lee S-H, Park I-C, Rhee C, Hong S-I (2006) Ionizing Radiation Enhances Matrix Metalloproteinase-2 Secretion and Invasion of Glioma Cells through Src/Epidermal Growth Factor Receptor-Mediated p38/Akt and Phosphatidylinositol 3-Kinase/Akt Signaling Pathways. Cancer Research 66 (17):8511-8519. doi:10.1158/0008-5472.can-05-4340

99. Huguenin P, Beer KT, Allal A, Rufibach K, Friedli C, Davis JB, Pestalozzi B, Schmid S, Thoni A, Ozsahin M, Bernier J, Topfer M, Kann R, Meier UR, Thum P, Bieri S, Notter M, Lombriser N, Glanzmann C (2004) Concomitant cisplatin significantly improves locoregional control in advanced head and neck cancers treated with hyperfractionated radiotherapy. $\mathrm{J}$ Clin Oncol 22 (23):4665-4673. doi:10.1200/JCO.2004.12.193

100. Bentzen J, Toustrup K, Eriksen JG, Primdahl H, Andersen LJ, Overgaard J (2015) Locally advanced head and neck cancer treated with accelerated radiotherapy, the hypoxic modifier nimorazole and weekly cisplatin. Results from the DAHANCA 18 phase II study. Acta oncologica 54 (7):1001-1007. doi:10.3109/0284186X.2014.992547

101. Chemoradiotherapy for Cervical Cancer Meta-Analysis C (2008) Reducing uncertainties about the effects of chemoradiotherapy for cervical cancer: a systematic review and meta-analysis of individual patient data from 18 randomized trials. J Clin Oncol 26 (35):5802-5812. doi:10.1200/JCO.2008.16.4368

102. Wild-Bode C, Weller M, Rimner A, Dichgans J, Wick W (2001) Sublethal irradiation promotes migration and invasiveness of glioma cells: implications for radiotherapy of human glioblastoma. Cancer research 61 (6):2744-2750

103. Qian L-W, Mizumoto K, Urashima T, Nagai E, Maehara N, Sato N, Nakajima M, Tanaka M (2002) Radiation-induced increase in invasive potential of human pancreatic cancer cells and its blockade by a matrix metalloproteinase inhibitor, CGS27023. Clinical cancer research : an official journal of the American Association for Cancer Research 8 (4):1223-1227 
104. Moncharmont C, Levy A, Guy J-B, Falk AT, Guilbert M, Trone J-C, Alphonse G, Gilormini M, Ardail D, Toillon R-A, Rodriguez-Lafrasse C, Magné N (2014) Radiation-enhanced cell migration/invasion process: A review. Critical Reviews in Oncology/Hematology 92 (2):133-142. doi:10.1016/j.critrevonc.2014.05.006

105. Ogata T, Teshima T, Kagawa K, Hishikawa Y, Takahashi Y, Kawaguchi A, Suzumoto Y, Nojima K, Furusawa Y, Matsuura N (2005) Particle irradiation suppresses metastatic potential of cancer cells. Cancer research 65 (1):113-120

106. Rieken S, Habermehl D, Wuerth L, Brons S, Mohr A, Lindel K, Weber K, Haberer T, Debus J, Combs SE (2012) Carbon Ion Irradiation Inhibits Glioma Cell Migration Through Downregulation of Integrin Expression. International Journal of Radiation Oncology*Biology*Physics 83 (1):394-399. doi:10.1016/j.ijrobp.2011.06.2004

107. Akino Y, Teshima T, Kihara A, Kodera-Suzumoto Y, Inaoka M, Higashiyama S, Furusawa Y, Matsuura N (2009) CarbonIon Beam Irradiation Effectively Suppresses Migration and Invasion of Human Non-Small-Cell Lung Cancer Cells. International Journal of Radiation Oncology*Biology*Physics 75 (2):475-481. doi:10.1016/j.ijrobp.2008.12.090

108. Oweida A, Sharifi Z, Halabi H, Xu Y, Sabri S, Abdulkarim B (2016) Differential response to ablative ionizing radiation in genetically distinct non-small cell lung cancer cells. Cancer Biology \& Therapy 17 (4):390-399. doi:10.1080/15384047.2016.1139241

109. Rieken S, Rieber J, Brons S, Habermehl D, Rief H, Orschiedt L, Lindel K, Weber KJ, Debus J, Combs SE (2015) Radiation-induced motility alterations in medulloblastoma cells. Journal of Radiation Research 56 (3):430-436. doi:10.1093/jrr/rru120

110. Narang H, Kumar A, Bhat N, Pandey BN, Ghosh A (2015) Effect of proton and gamma irradiation on human lung carcinoma cells: Gene expression, cell cycle, cell death, epithelial-mesenchymal transition and cancer-stem cell trait as biological end points. Mutation Research/Fundamental and Molecular Mechanisms of Mutagenesis 780:35-46. doi:10.1016/j.mrfmmm.2015.07.006

111. Zheng Q, Liu Y, Zhou HJ, Du YT, Zhang BP, Zhang J, Miao GY, Liu B, Zhang H (2015) X-ray radiation promotes the metastatic potential of tongue squamous cell carcinoma cells via modulation of biomechanical and cytoskeletal properties. Human \& Experimental Toxicology 34 (9):894-903. doi:10.1177/0960327114561664

112. Ishihara S, Yasuda M, Nishioka T, Mizutani T, Kawabata K, Shirato H, Haga H (2013) Irradiation-tolerant lung cancer cells acquire invasive ability dependent on dephosphorylation of the myosin regulatory light chain. FEBS Letters 587 (6):732736. doi:10.1016/j.febslet.2013.01.055

113. Lee S, Cheng H, Yuan Y, Wu S (2014) Regulation of Ionizing Radiation-Induced Adhesion of Breast Cancer Cells to Fibronectin by Alpha5beta1 Integrin. Radiation Research 181 (6):650-658. doi:10.1667/RR13543.1

114. Bacco F, Luraghi P, Medico E, Reato G, Girolami F, Perera T, Gabriele P, Comoglio PM, Boccaccio C (2011) Induction of MET by Ionizing Radiation and Its Role in Radioresistance and Invasive Growth of Cancer. JNCI: Journal of the National Cancer Institute 103 (8):645-661. doi:10.1093/jnci/djr093

115. Shen CJ, Sharma A, Vuong D-V, Erler JT, Pruschy M, Broggini-Tenzer A (2014) Ionizing radiation induces tumor cell lysyl oxidase secretion. BMC Cancer 14 (1):1-10. doi:10.1186/1471-2407-14-532

116. Lee S, Jeong E, Ju M, Jeon H, Kim M, Kim C, Park H, Han S, Kang H (2016) Induction of metastasis, cancer stem cell phenotype, and oncogenic metabolism in cancer cells by ionizing radiation. Molecular Cancer 16 (1):10. doi:10.1186/s12943016-0577-4

117. Gomez-Casal R, Bhattacharya C, Ganesh N, Bailey L, Basse P, Gibson M, Epperly M, Levina V (2013) Non-small cell lung cancer cells survived ionizing radiation treatment display cancer stem cell and epithelial-mesenchymal transition phenotypes. Molecular Cancer 12 (1):1-13. doi:10.1186/1476-4598-12-94

118. Ghisolfi L, Keates AC, Hu X, Lee D-k, Li CJ (2012) Ionizing Radiation Induces Stemness in Cancer Cells. PLoS ONE 7 (8). doi:10.1371/journal.pone. 0043628

119. Brunner TB, Kunz-Schughart LA, Grosse-Gehling P, Baumann M (2012) Cancer Stem Cells as a Predictive Factor in Radiotherapy. Seminars in Radiation Oncology 22 (2):151-174. doi:10.1016/j.semradonc.2011.12.003

120. Jung J-W, Hwang S-Y, Hwang J-S, Oh E-S, Park S, Han I-O (2007) Ionising radiation induces changes associated with epithelial-mesenchymal transdifferentiation and increased cell motility of A549 lung epithelial cells. European Journal of Cancer 43 (7):1214-1224. doi:10.1016/j.ejca.2007.01.034

121. Bae J-H, Park S-H, Yang J, Yang K, Yi J (2015) Stem cell-like gene expression signature identified in ionizing radiationtreated cancer cells. Gene 572 (2):285-291. doi:10.1016/j.gene.2015.08.005

122. Yuan W, Yuan Y, Zhang T, Wu S (2015) Role of Bmi-1 in Regulation of Ionizing Irradiation-Induced EpithelialMesenchymal Transition and Migration of Breast Cancer Cells. PLOS ONE 10 (3). doi:10.1371/journal.pone.0118799

123. Javaid S, Zhang J, Anderssen E, Black JC, Wittner BS, Tajima K, Ting DT, Smolen GA, Zubrowski M, Desai R, Maheswaran S, Ramaswamy S, Whetstine JR, Haber DA (2013) Dynamic Chromatin Modification Sustains EpithelialMesenchymal Transition following Inducible Expression of Snail-1. Cell Reports 5 (6):1679-1689. doi:10.1016/j.celrep.2013.11.034 
124. McDonald OG, Wu H, Timp W, Doi A, Feinberg AP (2011) Genome-scale epigenetic reprogramming during epithelialto-mesenchymal transition. Nature Structural \& Molecular Biology 18 (8):867-874. doi:10.1038/nsmb.2084

125. Bonner WM, Redon CE, Dickey JS, Nakamura AJ, Sedelnikova OA, Solier S, Pommier Y (2008) $\gamma \mathrm{H} 2 \mathrm{AX}$ and cancer. Nature reviews Cancer 8 (12). doi:10.1038/nrc2523

126. Weyemi U, Redon CE, Choudhuri R, Aziz T, Maeda D, Boufraqech M, Parekh PR, Sethi TK, Kasoji M, Abrams N, Merchant A, Rajapakse VN, Bonner WM (2016) The histone variant H2A.X is a regulator of the epithelial-mesenchymal transition. Nature Communications 7:10711. doi:10.1038/ncomms10711

127. Weyemi U, Redon CE, Sethi TK, Burrell AS, Jailwala P, Kasoji M, Abrams N, Merchant A, Bonner WM (2016) Twist1 and Slug mediate H2AX-regulated epithelial-mesenchymal transition in breast cells. Cell Cycle 15 (18):2398-2404. doi:10.1080/15384101.2016.1198864

128. Weyemi U, Redon CE, Bonner WM (2016) H2AX and EMT: deciphering beyond DNA repair. Cell cycle (Georgetown, Tex) 15 (10):1305-1306. doi:10.1080/15384101.2016.1160659

129. Park J, Jang S, Kang S, Park S, Hwang S-G, Kim W-J, Kang J, Um H-D (2012) Establishment of animal model for the analysis of cancer cell metastasis during radiotherapy. Radiation Oncology 7 (1):1-11. doi:10.1186/1748-717X-7-153

130. Zhang H, Luo H, Jiang Z, Yue J, Hou Q, Xie R, Wu S (2016) Fractionated irradiation-induced EMT-like phenotype conferred radioresistance in esophageal squamous cell carcinoma. Journal of Radiation Research 57 (4):370-380. doi:10.1093/jrr/rrw030

131. Meredith SL, Bryant JL, Babur M, Riddell PW, Behrouzi R, Williams KJ, White A (2016) Irradiation Decreases the Neuroendocrine Biomarker Pro-Opiomelanocortin in Small Cell Lung Cancer Cells In Vitro and In Vivo. PLOS ONE 11 (2). doi:10.1371/journal.pone.0148404

132. Carl C, Flindt A, Hartmann J, Dahlke M, Rades D, Dunst J, Lehnert H, Gieseler F, Ungefroren H (2016) Ionizing radiation induces a motile phenotype in human carcinoma cells in vitro through hyperactivation of the TGF-beta signaling pathway. Cellular and Molecular Life Sciences 73 (2):427-443. doi:10.1007/s00018-015-2003-2

133. Pan Y, Zhou C, Yuan D, Zhang J, Shao C (2016) Radiation Exposure Promotes Hepatocarcinoma Cell Invasion through Epithelial Mesenchymal Transition Mediated by H2S/CSE Pathway. Radiation Research 185 (1):96-105. doi:10.1667/RR14177.1

134. Vilalta M, Rafat M, Graves EE (2016) Effects of radiation on metastasis and tumor cell migration. Cellular and Molecular Life Sciences 73 (16):2999-3007. doi:10.1007/s00018-016-2210-5

135. Eberle F, Saulich MF, Leinberger FH, Seeger W, Engenhart-Cabillic R, Dikomey E, Hänze J, Hattar K, Subtil F (2016) Cancer cell motility is affected through 3D cell culturing and SCF/c-Kit pathway but not by X-irradiation. Radiotherapy and Oncology 119 (3):537-543. doi:10.1016/j.radonc.2016.04.036

136. Das A, McDonald D, Lowe S, Bredlau A-L, Vanek K, Patel SJ, Cheshier S, Eskandari R (2016) Immunological low-dose radiation modulates the pediatric medulloblastoma antigens and enhances antibody-dependent cellular cytotoxicity. Child's Nervous System 33 (3):429-436. doi:10.1007/s00381-016-3305-x

137. Roth B, Gibhardt CS, Becker P, Gebhardt M, Knoop J, Fournier C, Moroni A, Thiel G (2015) Low-dose photon irradiation alters cell differentiation via activation of hIK channels. Pflügers Archiv - European Journal of Physiology 467 (8):1835-1849. doi:10.1007/s00424-014-1601-4

138. Weichselbaum RR, Liang H, Deng L, Fu YX (2017) Radiotherapy and immunotherapy: a beneficial liaison? Nat Rev Clin Oncol 14 (6):365-379. doi:10.1038/nrclinonc.2016.211

139. Deng L, Liang H, Burnette B, Beckett M, Darga T, Weichselbaum RR, Fu YX (2014) Irradiation and anti-PD-L1 treatment synergistically promote antitumor immunity in mice. The Journal of clinical investigation 124 (2):687-695. doi:10.1172/JCI67313

140. Antonia SJ, Villegas A, Daniel D, Vicente D, Murakami S, Hui R, Yokoi T, Chiappori A, Lee KH, de Wit M, Cho BC, Bourhaba M, Quantin X, Tokito T, Mekhail T, Planchard D, Kim YC, Karapetis CS, Hiret S, Ostoros G, Kubota K, Gray JE, Paz-Ares L, de Castro Carpeno J, Wadsworth C, Melillo G, Jiang H, Huang Y, Dennis PA, Ozguroglu M, Investigators P (2017) Durvalumab after Chemoradiotherapy in Stage III Non-Small-Cell Lung Cancer. The New England journal of medicine. doi:10.1056/NEJMoa1709937

141. Formenti SC, Demaria S (2013) Combining radiotherapy and cancer immunotherapy: a paradigm shift. J Natl Cancer Inst 105 (4):256-265. doi:10.1093/jnci/djs629

142. Poleszczuk J, Luddy K, Chen L, Lee JK, Harrison LB, Czerniecki BJ, Soliman H, Enderling H (2017) Neoadjuvant radiotherapy of early-stage breast cancer and long-term disease-free survival. Breast cancer research : BCR 19 (1):75. doi:10.1186/s13058-017-0870-1

143. Choi JW, Kim JK, Yang YJ, Kim P, Yoon KH, Yun SH (2015) Urokinase exerts antimetastatic effects by dissociating clusters of circulating tumor cells. Cancer Res 75 (21):4474-4482. doi:10.1158/0008-5472.CAN-15-0684 
144. Fidler IJ (2003) The pathogenesis of cancer metastasis: the 'seed and soil' hypothesis revisited. Nat Rev Cancer 3 (6):453458. doi:10.1038/nrc1098

145. Giancotti FG (2013) Mechanisms governing metastatic dormancy and reactivation. Cell 155 (4):750-764. doi:10.1016/j.cell.2013.10.029 